\title{
Outcome Evaluation of Patients with Burst Thoracolumbar Fractures: A Case Series
}

\section{Avaliação de resultados de pacientes com fraturas toracolombares do tipo explosão: Uma série de casos}

\author{
Mohammad Jamali $^{1}$ Yashar Goorakani ${ }^{2}$ Niloofar Solat ${ }^{2}$ Reza Taheri ${ }^{1}$ Sulmaz Ghahramani ${ }^{3}$ \\ ${ }^{1}$ Department of Neurosurgery, Shiraz University of Medical Sciences, \\ Shiraz, Iran \\ 2 Student Research Committee, Fasa University of Medical Sciences, \\ Fasa, Iran \\ ${ }^{3}$ Health Policy Research Center, Institute of Health, Shiraz University \\ Address for correspondence Sulmaz Ghahramani, MD, Health Policy \\ Research Center, Institute of Health, Shiraz University of Medical \\ Sciences, Building No 2, Eighth Floor, Zand Avenue, Shiraz, Iran. \\ 71348-45794 (e-mail: suli.ghahraman@gmail.com).
} of Medical Sciences, Shiraz Iran

Arq Bras Neurocir 2018;37:304-308.

\begin{abstract}
Objective The aim of the present study was to evaluate the outcome of short segment instrumentation in patients affected by burst thoracolumbar fractures.

Methods A total of 19 patients with unstable burst fractures of the thoracolumbar spine were eligible for short segment instrumentation. Their functional outcome (by using the Oswestry and Denis scales) and back pain (using the visual analog scale) were evaluated after 12 months.

Results The mean age of the patients was 30.7 years old, and most of them were male $(n=15)$. The mean hospital stay was 4.6 days. The mean \pm standard deviation (SD) of the pain score according to the visual analog scale was $1.63 \pm 1.25$ after 12 months of surgery, and there were no patients classified with grades 4 or 5 on the Denis work scale. The average Oswestry disability index (ODI) was $17 \%$ during the follow-ups.

\section{Keywords \\ - outcome \\ - burst thoracolumbar fractures}

\section{Resumo}

Conclusions The outcome of the studied patients, including the clinical pain and the functional outcome of postsurgical patients, suggested that the short-segment instrumentation could be an appropriate method for patients with unstable thoracolumbar junction fractures. However, a long-term follow-up is recommended.

Objetivo O presente estudo visa avaliar o resultado de instrumentação segmentar curta em pacientes afetados por fraturas toracolombares do tipo explosão.

Métodos Um total de 19 pacientes com fraturas do tipo explosão instáveis na espinha toracolombar foram elegíveis para instrumentação segmentar curta. O resultado funcional (usando as escalas de Oswestry e Denis) e dor nas costas (usando a escala visual analógica da dor) foi avaliado após 12 meses.

Resultados A idade média dos pacientes era de 30,7 anos, sendo a maioria homens $(n=15)$. A média de internação hospitalar foi de 4,6 dias. O desvio padrão $(\sigma)$ da pontuação de dor, de acordo com a escala visual analógica foi de 1,63 a 1,25 após
\end{abstract}

received

May 22, 2018

accepted

August 31, 2018

published online

November 6, 2018
Copyright $\odot 2018$ by Thieme Revinter

Publicações Ltda, Rio de Janeiro, Brazil
License terms

(c) (i) $\ominus$ (\$)
$10.1055 / \mathrm{s}-0038-1675223$.

ISSN 0103-5355. 
12 meses de cirurgia, não havendo pacientes classificados com graus quatro ou cinco na escala de trabalho de Denis. A média da pontuação de incapacidade de Oswestry foi

Palavras Chave

- resultado

- fraturas toracolombares do tipo explosão de $17 \%$ durante o acompanhamento.

Conclusões Os resultados dos pacientes estudados, incluindo a dor clínica e o resultado funcional de pacientes pós-cirúrgicos, sugeriu que a instrumentação segmentar curta pode ser um método apropriado para pacientes com fraturas instáveis nas junções toracolombares. No entanto, um acompanhamento de longo prazo é recomendado.

\section{Introduction}

Thoracolumbar fracture is the most common type of spine fracture. $^{1,2}$ Falling and motor vehicle accidents are among the most common causes of thoracolumbar injuries. ${ }^{3}$ Burst fracture of the spine is a serious injury that commonly occurs among young people. Thoracolumbar burst fracture is defined as a fracture in the anterior and middle column of the spine, secondary to an axial pressure. ${ }^{4}$ Patients are prone to serious disorders, which can be life threatening, as well as to postoperative problems, such as pressure sores, deep venous thrombosis, and pulmonary infections. ${ }^{2,5,6}$

An unstable burst fracture of the thoracolumbar spine is an indication for instrumentation. Unstable fractures are burst fractures that involve the posterior column of the vertebrae and the tearing of the posterior longitudinal ligament. ${ }^{7}$ Short and long segment instrumentation are two different choices for internal fixation. ${ }^{4}$ The short segment instrumentation is the fixation of bilateral pedicle screws one normal level above and one normal vertebra below the injured segment. In contrast, long segment instrumentation is the fixation of two segments above and two segments below the fractured vertebrae. ${ }^{8}$ Surgeons desire to minimize the number of vertebral levels that are involved in the instrumentation process. ${ }^{9}$ The development of transpedicular screw instrumentation techniques and of instrumentation systems has brought short segment instrumentation into the general clinical practice. ${ }^{10}$ However, the optimal management of thoracolumbar fractures is controversial. ${ }^{11}$

The short segment posterior instrumentation can reduce the bleeding and preserve segmental motion with an acceptable anatomic and functional outcome. ${ }^{4}$ Short-term followup results have suggested a favorable outcome in short segment instrumentation. ${ }^{12-15}$ Although there are reports of high percentages in instrumentation failure, verifying its longer-term evaluation is required. ${ }^{16,17}$

Therefore, we have aimed to evaluate the outcome of sixscrew instrumentation (short segment) in the treatment of burst fractures, measuring postoperative pain and neurologic deficits after 12 months of surgery.

\section{Methods}

\section{Study Population}

From December 2014 to July 2016, 19 new thoracolumbar (T11 to L3) burst fracture patients (15 males and 4 females) with an average age of 30.7 years old (range: $18-59$ years old) were operated on with the short segment transpedicular fixation method by a neurosurgeon in the Fasa Valiasr Hospital. This hospital is a general hospital located in the Fars province, Iran.

All of the patients underwent plain X-rays, computed tomography (CT), and magnetic resonance imaging (MRI) exams. On arrival, the patients underwent a full neurologic examination, which was assessed with the Frankel classification by the neurosurgeon. Then, the patients were followedup after 12 months. The inclusion criteria were (a) a single level fracture between the T11 and the L3; (b) only short segment instrumentation (one-above, one-below, and the fractured vertebra); (c) a local kyphotic angle $>30$ degrees, or an anterior height collapse $>50 \%$, or spinal canal involvement $>50 \%$. A written informed consent was obtained from each patient.

\section{Surgical Technique}

The patients were placed in the prone position under general anesthesia. Before the incision, the fracture level was determined under C-Arm control. A midline linear thoracolumbar incision was routinely done from one vertebral body above the fractured site to one vertebral body below it. After cutting the fascia and stripping the prevertebral muscles, a subperiosteal dissection was performed to decrease bleeding. According to the CT and MRI exams of the patients, a laminectomy was performed in the patients who had a neurologic deficit secondary to cord compression or canal compromise $>50 \%$. After the procedure, a physical exam was performed, and anteroposterior and lateral X-rays were taken.

\section{Postoperative Care and Follow-up Evaluation}

All of the patients were encouraged to walk after 24 to 48 hours postoperatively, and the brace was applied for between 4 and 6 weeks. The medical records of every patient, including age, gender, injury level, fracture type, the cause of injury, underlying diseases, operative time, blood loss, the extent of the fixation, and perioperative complications, were collected. A visual analog scale (VAS) was assigned to evaluate back pain. ${ }^{18}$ The Oswestry disability index (ODI) was used to evaluate the postoperative function. ${ }^{19}$ The final clinical results were assessed using the Denis scale, which is a 5-point scale that includes both work and pain scales. ${ }^{20}$ 


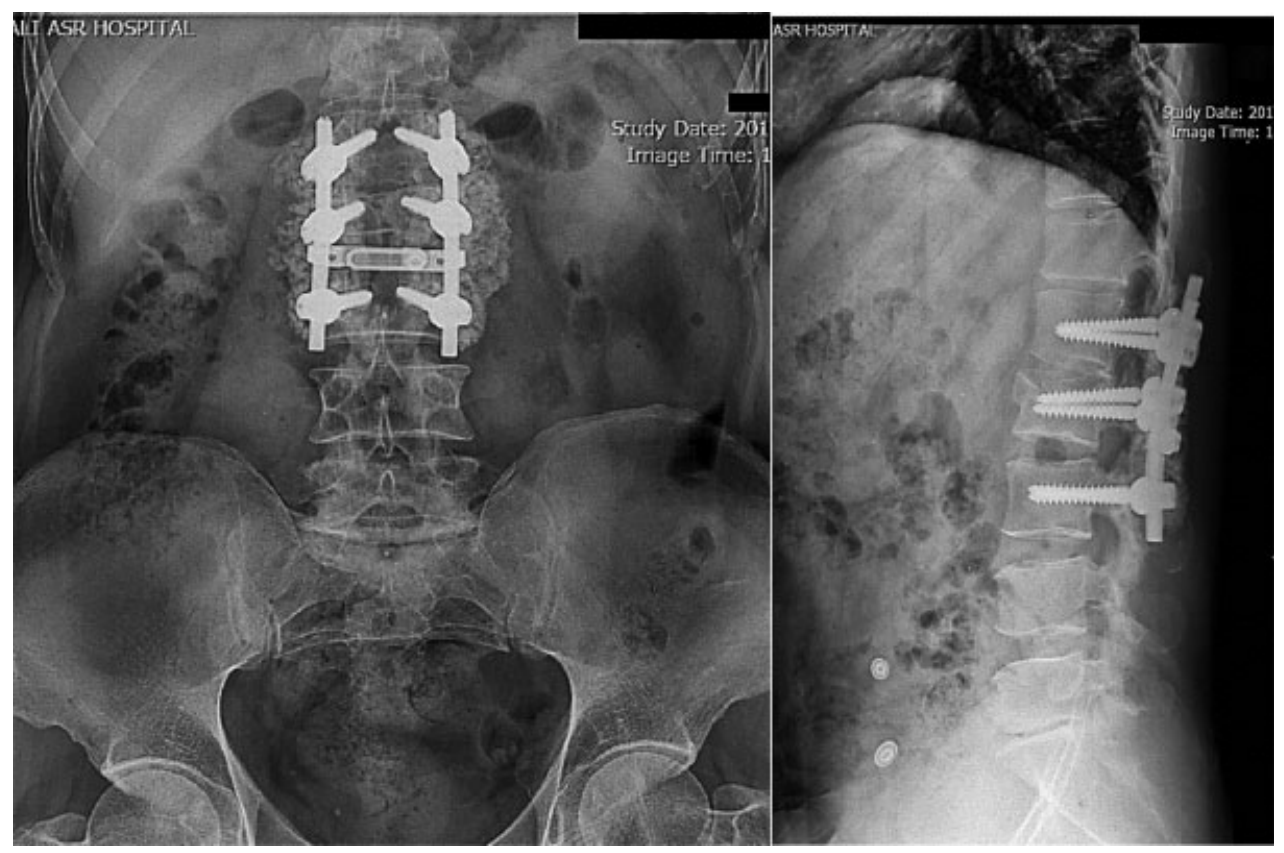

Fig. 1 Postoperative biplanar radiography.

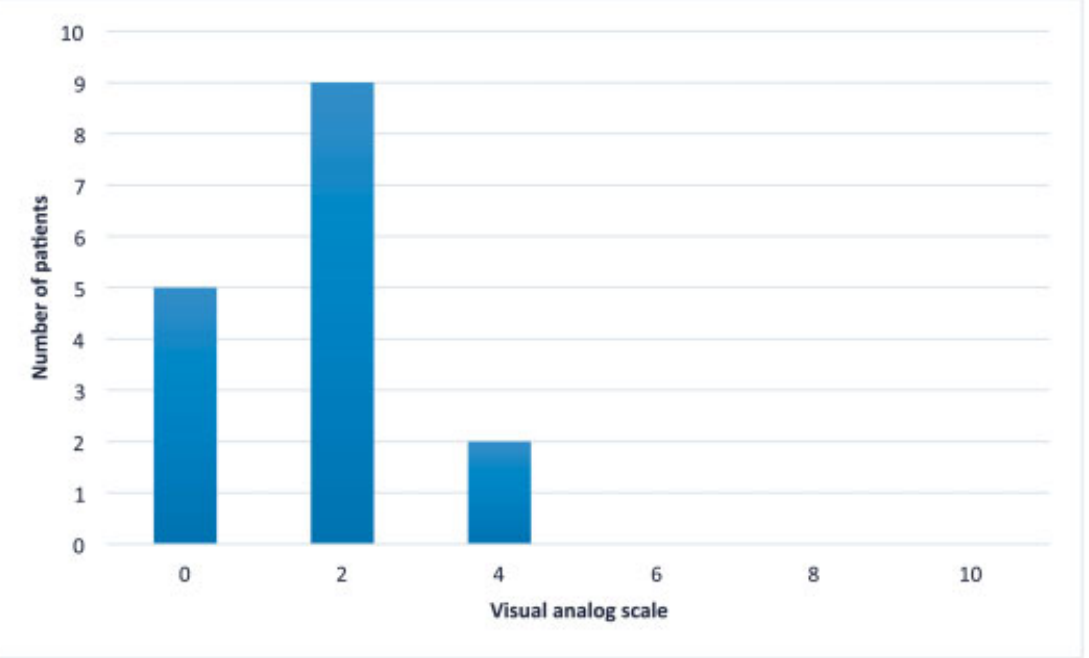

Fig. 2 Distribution of patients in different pain scores after the operation according to the visual analogue scale.

\section{Statistical Analysis}

Data were analyzed using software STATA version 12 (StataCorp, College Station, TX, USA).

\section{Results}

During the study period, 19 patients with unstable thoracolumbar fractures were operated, using short segment posterior spinal six-screw instrumentation (-Fig. 1). The study population included 15 men and 4 women, with a mean age of 30.7 years old (range: 18-59 years old). The causes of the thoracolumbar fractures were motor vehicle accidents ( 11 cases) and falling from heights ( 8 cases). The most common vertebra involved was the L1 (47.36\%), followed by the T12 (26.31\%), the L2 (10.52\%), the L3 (5.26\%), the L4 (5.26\%), and the L5 (5.26\%). One of the patients had uncontrolled diabetes. None of the patients were affected by hypertensive disease, coagulopathies, or chronic illnesses. One patient was a smoker, and one patient was addicted to heroin. None of the patients complained of any previous trauma before the injury, but three patients had previous back pain. The mean \pm standard deviation (SD) surgical time was $70 \pm 11$ minutes (range 60-90 minutes) and the mean \pm SD intraoperative blood loss was 126-27 ml (range: 90-170 ml). The mean hospital stay was 4.6 days. Laminectomy was performed in 9 patients. The reason for laminectomy was the presence of a preoperative neurologic problem, which appeared in two patients (sphincter problem and saddle hypoesthesia in 1 case and motor deficit (Frankle D) in 1 case, which resolved after the operation in both patients. The other 7 patients had a canal compression $>50 \%$. 
Table 1 Distribution of patients classified by the Denis work scale

\begin{tabular}{|l|l|l|}
\hline Criteria & Grade & N\% \\
\hline $\begin{array}{l}\text { Return to previous employment } \\
\text { (heavy labor) or physically } \\
\text { demanding activities }\end{array}$ & 1 & $9(47.36 \%)$ \\
\hline $\begin{array}{l}\text { Able to return to previous } \\
\text { employment (sedentary) or } \\
\text { return to heavy labor with lifting } \\
\text { restrictions }\end{array}$ & 2 & $7(36.84 \%)$ \\
\hline $\begin{array}{l}\text { Unable to return to previous } \\
\text { employment, but working } \\
\text { full-time at a new job }\end{array}$ & 3 & $3(15.78 \%)$ \\
\hline Unable to return to full-time work & 4 & $0(0 \%)$ \\
\hline No work, completely disabled & 5 & $0(0 \%)$ \\
\hline Total & & $19(100.0 \%)$ \\
\hline
\end{tabular}

Table 2 Distribution of patients classified by the Denis pain scale

\begin{tabular}{|l|l|l|}
\hline Criteria & Grade & N\% \\
\hline No pain & 1 & $12(63.15 \%)$ \\
\hline $\begin{array}{l}\text { Occasional, minimal pain, no } \\
\text { need for medication }\end{array}$ & 2 & $6(31.57 \%)$ \\
\hline $\begin{array}{l}\text { Moderate pain, occasional medi- } \\
\text { cation, no interruption of work or } \\
\text { activities of daily life }\end{array}$ & 3 & $1(5.26 \%)$ \\
\hline $\begin{array}{l}\text { Moderate to severe pain, } \\
\text { occasional absences from } \\
\text { work, significant changes in } \\
\text { activities of daily life }\end{array}$ & 4 & $0(0 \%)$ \\
\hline $\begin{array}{l}\text { Constant severe pain, chronic } \\
\text { medication }\end{array}$ & 5 & $0(0 \%)$ \\
\hline Total & & $19(100.0 \%)$ \\
\hline
\end{tabular}

All of the patients were assessed 12 months after surgery and evaluated for pain at the time of follow-up. The average pain score according to the VAS was $1.63 \pm 1.25$ (- Fig. 2). The patients were classified according to the Denis work scale. The patients were predominantly categorized in grade 1 and 2 (-Table1). The patients were also classified according to the Denis pain scale. There were no grades 4 or 5 (-Table 2). Also, the mean postoperative ODI was $37 \%$ after the one-month follow-up. In the most recent follow-up, the average ODI was minimal, at $17 \%$. A patient had Frankle D and a patient had urinary retention with saddle hypoesthesia. Both of them improved after the operation without any signs of neurologic problems.

\section{Discussion}

The result of the present study shows that the majority of the patients with thoracolumbar fractures were young people in the functional years of their lives who required treatments that would facilitate their functional state and enable a reduction in complications. Most of the fractures were caused by motor vehicle accidents and involved more men than women, which is in line with Western studies. ${ }^{21,22}$

The results of the present study corroborate the reported benefits of pedicle screws in the fractured vertebra and the efficacy of the six-screw construct for the treatment of thoracolumbar burst fractures. Pellise showed that the sixscrew construct, a short-segment instrumentation including the fractured level, is an efficient procedure for the treatment of thoracolumbar burst fractures. ${ }^{23}$ It was reported that the prevalence of posterior instrumentation failure ranged from 9 to $54 \%{ }^{24,25}$ However, no failure was observed in the present study.

Low blood loss and short operation times were also two other favorable achievements. The similarity of our results with previously published surgical data (surgical time and blood loss), surgical correction, and postoperative correction loss suggest that the short-segment six-screw technique is feasible. ${ }^{23}$ Uzumcugil et al noted that the average hospital stay was 24 days, which was 4.6 days longer than in our study. ${ }^{26}$ Gajjar et al suggested that this difference in the duration of hospital stay might be due to the referral from one center to another from distant places and to the waste of valuable time for the much-required surgery. ${ }^{5}$

In the present study, postoperative pain in the VAS and in the Denis pain scale was low. Most cases did not involve severe pain, suggesting that this surgical method can reduce both resting time and activity-induced pain. The patients showed a satisfactory ability to return to their previous employments (sedentary) or to return to heavy labor with some lifting restrictions, or even physically demanding activities, according to the Denis work scale and to the ODI questionnaires, which shows that this method could also improve the functional outcome, especially in young patients.

However, we suggest further studies with a longer followup and a larger sample size to provide a more conclusive result.

\section{Conclusion}

The outcome of the studied patients, including operation time, blood loss, transfusion requirement, and postsurgical clinical pain and functional outcome of the patient suggested that the short-segment instrumentation could be an appropriate method for patients with unstable thoracolumbar junction fracture. However, a long-term follow-up is recommended.

\section{Funding \\ None.}

Conflict of Interests

The authors have no conflicts of interests to declare.

\section{Acknowledgments}

The authors would like to thank the patients for their cooperation and the staff of the hospital. The authors would like to thank Mr. H. Argasi at the Research Consultation Center (RCC) of the Shiraz University of Medical 
Sciences for his invaluable assistance in editing this manuscript.

\section{References}

1 Vu TT, Morishita Y, Yugue I, Hayashi T, Maeda T, Shiba K. Radiological outcome of short segment posterior instrumentation and fusion for thoracolumbar burst fractures. Asian Spine J 2015;9 (03):427-432

2 Wood K, Buttermann G, Mehbod A, Garvey T, Jhanjee R, Sechriest $\mathrm{V}$. Operative compared with nonoperative treatment of a thoracolumbar burst fracture without neurological deficit. A prospective, randomized study. J Bone Joint Surg Am 2003;85-A(05): 773-781

3 Inamasu J, Guiot BH, Nakatsukasa M. Posterior instrumentation surgery for thoracolumbar junction injury causing neurologic deficit. Neurol Med Chir (Tokyo) 2008;48(01):15-21, discussion 21

4 Farrokhi MR, Razmkon A, Maghami Z, Nikoo Z. Inclusion of the fracture level in short segment fixation of thoracolumbar fractures. Eur Spine J 2010;19(10):1651-1656

5 Gajjar SH, Menon HJ, Chaudhari N, Chaudhari V. Outcomes of Short Segment Posterior Instrumentation in Unstable Thoracolumbar Fractures. J Clin Diagn Res 2016;10(11):RC04-RC08

6 Khare S, Sharma V. Surgical outcome of posterior short segment trans-pedicle screw fixation for thoracolumbar fractures. J Orthop 2013;10(04):162-167

7 Petersilge CA, Emery SE, Eds. Thoracolumbar burst fracture: evaluating stability. Elsevier: Seminars in Ultrasound, CT and MRI; 1996

8 Tang J, Liu Y, Cao Z, Hu Y, Lu X, Lin B. Short segment screw fixation without fusion in treatment for unstable thoracolumbar burst fracture. Int J Clin Exp Med 2014;7(12):5681-5685

9 Jonathan-James TE, Chen JL, Mitsunaga MM. Short same-segment fixation of thoracolumbar burst fractures. Hawaii J Med Public Health. 2010;10(09):S109

10 Shin TS, Kim HW, Park KS, Kim JM, Jung CK. Short-segment pedicle instrumentation of thoracolumbar burst-compression fractures; short term follow-up results. J Korean Neurosurg Soc 2007;42 (04):265-270

11 Chen C, Lv G, Xu B, Zhang X, Ma X. Posterior short-segment instrumentation and limited segmental decompression supplemented with vertebroplasty with calcium sulphate and intermediate screws for thoracolumbar burst fractures. Eur Spine J 2014;23(07):1548-1557

12 Yung AW, Thng PL. Radiological outcome of short segment posterior stabilisation and fusion in thoracolumbar spine acute fracture. Ann Acad Med Singapore 2011;40(03):140-144
13 Roy-Camille R, Roy-Camille M, Demeulenaere C. [Osteosynthesis of dorsal, lumbar, and lumbosacral spine with metallic plates screwed into vertebral pedicles and articular apophyses]. Presse Med 1970;78(32):1447-1448

14 Sargın S, Uccedil BY, Necmioğlu S, Bulut M, Gem M. Clinical and radiological results of posterior instrumentation without fusion for thoracolumbar fractures. Afr J Pharm Pharmacol 2011;5(07): 819-822

15 Lee YS, Sung JK. Long-term follow-up results of short-segment posterior screw fixation for thoracolumbar burst fractures. J Korean Neurosurg Soc 2005;37:416-421

16 McLain RF, Sparling E, Benson DR. Early failure of short-segment pedicle instrumentation for thoracolumbar fractures. A preliminary report. J Bone Joint Surg Am 1993;75(02):162-167

17 Kramer DL, Rodgers WB, Mansfield FL. Transpedicular instrumentation and short-segment fusion of thoracolumbar fractures: a prospective study using a single instrumentation system. J Orthop Trauma 1995;9(06):499-506

18 Huskisson EC. Measurement of pain. Lancet 1974;2(7889): 1127-1131

19 Walsh TL, Hanscom B, Lurie JD, Weinstein JN. Is a conditionspecific instrument for patients with low back pain/leg symptoms really necessary? The responsiveness of the Oswestry Disability Index, MODEMS, and the SF-36. Spine 2003;28(06):607-615

20 Denis F, Armstrong GW, Searls K, Matta L. Acute thoracolumbar burst fractures in the absence of neurologic deficit. A comparison between operative and nonoperative treatment. Clin Orthop Relat Res 1984;(189):142-149

21 An HS, Vaccaro A, Cotler JM, Lin S. Low lumbar burst fractures. Comparison among body cast, Harrington rod, Luque rod, and Steffee plate. Spine 1991;16(8, Suppl)S440-S444

22 Roy-Camille R, Saillant G, Berteaux D, Salgado V. Osteosynthesis of thoraco-lumbar spine fractures with metal plates screwed through the vertebral pedicles. Reconstr Surg Traumatol 1976; 15:2-16

23 Pellisé F, Barastegui D, Hernandez-Fernandez A, et al. Viability and long-term survival of short-segment posterior fixation in thoracolumbar burst fractures. Spine J 2015;15(08):1796-1803

24 McLain RF, Burkus JK, Benson DR. Segmental instrumentation for thoracic and thoracolumbar fractures: prospective analysis of construct survival and five-year follow-up. Spine J 2001;1(05): 310-323

25 McCormack T, Karaikovic E, Gaines RW. The load sharing classification of spine fractures. Spine 1994;19(15):1741-1744

26 Uzumcugil O, Dogan A, Yetis M, Yalcinkaya M, Caniklioglu M. Results of 'two above- one below approach' with intermediate screws at the fracture site in the surgical treatment of thoracolumbar burst fractures. Kobe J Med Sci 2010;56(02):E67-E78 